\title{
Introducing the Visual Art through Concrete Poetry in the EFL Classroom: A Case Study
}

Chahra BELOUFA

Faculty of Arts and Foreign Languages, Djilali Liabes University, Sidi Bel Abbes, Algeria

Chahra.beloufa@gmail.com

DOI: http://doi.org/ 10.36892/ijlls.v3i4.765

\begin{tabular}{|c|c|}
\hline $\begin{array}{l}\text { Received: } \\
\text { 16/11/2021 }\end{array}$ & $\begin{array}{l}\text { Abstract } \\
\text { Teaching poetry offers the teacher of literature some basic and active ways to }\end{array}$ \\
\hline $\begin{array}{l}\text { Accepted: } \\
\text { 23/11/2021 }\end{array}$ & $\begin{array}{l}\text { engage students in learning English because of poetry's rich language which } \\
\text { represents an opportunity for learners to explore meanings and be able to } \\
\text { formulate creative responses. One must be aware of the fact that poetry includes }\end{array}$ \\
\hline $\begin{array}{l}\text { Keywords: } \\
\text { Concrete poetry, } \\
\text { Visual poetry, EFL } \\
\text { classroom, teaching } \\
\text { poetry }\end{array}$ & $\begin{array}{l}\text { various types which differ in forms, and each one of these may have a particular } \\
\text { influence on students" learning literature; that is why one centralized the } \\
\text { research area on concrete poetry or what is called visual poetry too. This study } \\
\text { aims to teach students not only to read and listen to a poem but to develop the } \\
\text { skill of creativity through rewriting and this ability would be provoked by the } \\
\text { visual shape of the concrete poem. One is trying to bring fun in the EFL } \\
\text { classroom and particularly during the literature lecture where students are } \\
\text { probably bored by analyzing every line and stanza. So, all these aims were to } \\
\text { be concrete via a test, observation and questionnaire. These scientific tools } \\
\text { confirmed one's hypotheses about how positive is concrete poetry for the group } \\
\text { of the third-year English L.M.D. students at the University of Djilali Liabes, } \\
\text { Sidi Bel Abbes }\end{array}$ \\
\hline
\end{tabular}

\section{INTRODUCTION}

Learners of English as a Foreign Language (EFL) need to have some knowledge and literary background about the target language and this is acquired to some extent and reinforced during lectures of literature. Literature incorporates various subjects often distinguished as literary genres, so the content of the lecture always contains for example a literary piece belonging to one of the main literary divisions whether drama, fiction, or poetry. Students are found to be interested in some of these genres and may dislike some others. As a general opinion, students tend to consider poetry difficult than prose and this can lead them to stress whenever they face this kind of literary piece of writing. Yet, when studying poetry or a poem are students aware of its potential towards their language skills?

Teaching poetry in the EFL classroom may be challenging for teachers and difficult for students since poetry"s genres and forms differ from one to another. Students may be unable to grasp the poem"s image and its dominant theme, as well as, the teacher may be incapable to convey and translate the poet"s conceptualization of the described theme.

Does concrete poetry enhance EFL students"skills and foster their learning poetry? Then after reviewing the literature of this genre of poetry the researcher could resume the following hypotheses: 


\section{Introducing the Visual Art through Concrete Poetry in the EFL Classroom: A Case Study}

1. Concrete poetry may stimulate EFL students ${ }^{\text {ee }}$ creative thoughts and imagination.

2. It may allow students to interact actively in the classroom by listening, reading, speaking, or writing.

3. Concrete poetry may be an easy and funny genre for EFL students of "Licence, Master and Doctorate" (L.M.D.) that can make them enthusiastic about their learning literature in general and poetry in particular.

The researcher aims to foster students" ability of recognizing shapes and develop their imagination skill.The population of interest in the course of the present research includes a group of forty six third year L.M.D. students. We aimed to make them acquainted with concrete poetry. The aim of the research is to discover the difficulties and the obstacles to be considered during teaching concrete poetry and trying to figure the right method and techniques which would guide them to a successful concrete poetry course. Another objective is to consider the importance and the value of concrete poetry and if the mentioned hypotheses are confirmed, it will be appropriate to think about our suggestions to improve the quality of students" learning and make teachers of literature think of how visual poetry can be interesting for learners.

\section{LITERATURE REVIEW}

The researcher"s choice to this kind of poetry was not randomly made, yet after analyzing its interesting form she suggested its probable usefulness to L.M.D. students where they could explore it. The concept of concrete poetry means something one can see, something primarily explicit and not hidden, which may allow students an easy and quick understanding to the poem "s main subject. To be clearer, the researcher will provide some definitions and a theoretical framework about this paper"s dominant concept. Concrete poetry is a type of poetry which is referred to it too by pattern or shape poetry. This term has been coined when an experimental movement was inaugurated, yet it has Greek roots called where it was initially named pattern poetry. Each genre of poetry has particular features which differentiate it from the other ones.

The present type is different in terms of "shape" or "form". A concrete poem main aspect is how words are put in the page regarding space and the wordse position which all constitute a visual representation. The form is inseparable from the content, in other words, the shape suggests and mimes the subject of the poem. To illustrate the definition below here is an example of a "concrete poem" written by George Herbert who is an English poet; orator and priest entitled "the Altar" (1633). As one can observe the poem's title is exposed in the shape. The visual appearance of the poem is the primary element which attracts the attention of the reader which will guide him to identify and guess the poem's theme. Some researchers consider concrete poetry as a genre of visual poetry where the visual elements dominate the poem that is the way letters are written aim to produce a particular effect establishing the image in the reader's mind, as it is asserted in Higgins statement about concrete poetry: "Visual poetry: poetry in which the visual element predominates. The best known genre of visual poetry is concrete poetry, modern poems using letters of the alphabet in a visual way." (Higgins 1984:193)

One may ask what a concrete poem shows. How does it function? And mainly when reading Higgins definition one inquires what is the difference between visual and concrete poetry? The distinction is clarified as follows:

"The former usually consisted of arrays of letters or words, while the latter are for more visual then verbal or textual: many consist of photographs of people carrying words or even 
letters, others show". Concrete poetry is strictly words or only letters which make up a concrete image. It has various kinds which are distinguished according to each one ${ }^{\text {ee }}$ s construction and its function; what it does convey. Concrete poetry is divided into three basic types and which are: visual, phonetic, and kinetic. The visual poem is also called optic; its objective is to be seen like a painting. It depends primarily on the visual appearance; usually this kind of poetry cannot be read out aloud. This kind is intended to liberate poetry from the linear method of the printed page.

As for the phonic poem, it is related to spoken sound only. It is also known as "sound poetry" or "ear poetry". The ear poem began during the French Dadaist movement. These poems are composed to be listened like music, so the impact can only be found in the hearing. Here is a concrete example; "Julia's Wild" of Louis Zukofskoy. The last type which is the kinetic poem is an action poem; it can be compared to drama where words perform in motion; it is a visual figure which produces the effect of movement; it can visualize the succession of an event too. As an example of this poem appeared in the third chapter of Alice in Wonderland and it is printed in tail mimicking a certain moves acted out through words.

David Holbrook (1961) argued about teaching poetry: “...teaching poetry is the centre of English". Yet one may inquire are all types of poetry efficient for foreign language learners? Does concrete poetry produce any results in a foreign language classroom? As a prior advantage which concrete poetry may have is its visual feature which may be is appealing to imagine; leaving the students enough freedom to join the depicted experience of the poem through its pattern. Observing the structure of concrete poems some may think it is inappropriate in an EFL classroom because of some grammatical problems. So, for the researcher's present study is it an obstacle for students?

The visual appearance of concrete poems may state the message instantly. When students read, they could be guided and helped by the design, in such a manner of discovery; exploring the movement of words which evolve and change before their eyes. This visual experience of words and image may provoke connotative meaning of words. The latter effect can be produced by mainly "kinetic poems" whose words are in a continuous motion where "they become actors and dancers on the stage of the computer screen" (Ryan 13). Dealing with such a poem may push students to participate actively in the classroom either by reading, hearing, speaking or rewriting. It is noticeable that concrete poems reject punctuation which leaves students make their own personal interpretation that may enhance their critical thinking. In addition, the use of concrete poetry in the classroom could bring an enjoyable atmosphere and a relaxing one as Albert B. Somers explains in his Teaching Poetry in High School, concrete poems are "fun and easy" (135). Concrete poetry represents an art; designed patterns with may be redundant words or moving ones that can encourage students to be creative.

\section{METHODOLOGY}

This research is based on testing concrete poetry. It is commonly known that poetry is a highly sophisticated language to be studied by students who master to some extent the English language. That is why the researcher decided to apply the test on the two groups among the third year L.M.D. students. The whole number of the 3rd year L.M.D. students is one hundred and sixty-one students grouped as; A, B, C, and D. Students from both groups $\mathrm{C}$ and $\mathrm{D}$ who were forty-six have been tested objectively without being informed under natural circumstances in their lecture of literature. The latter groups have a prior knowledge about poetry; they have been introduced to definitions of the different types of poetry; they have also been trained on the stylistic devices containing in a literary piece. One can inquire why these groups particularly and not the former ones. The reason is due to the consideration of the time limit of the research; one found that these groups are the 


\section{Introducing the Visual Art through Concrete Poetry in the EFL Classroom: A Case Study}

appropriate ones, that is to say that the test scheduled can be an integral part of their literature programme.

The test took two sessions, in other words, three hours. Before the test with a week students were asked by their teacher to have a copy of the poem "Swan and Shadow" of John Hollander, they were also supposed to make researches about it. The first hour and half was dedicated to reading the poem and introducing the concrete poetry genre and getting acquainted with the poet. Where in the other hour and half students exchanged their impressions and views about the poem se theme and their feeling about the introduced genre "concrete poetry". Within the test the researcher undertook a questionnaire and an observation which was responding to the predicted students ${ }^{\text {ce }}$ reactions.

As it is mentioned before the teacher has been furnished with some instructions in order to get objective and reliable results and a structured lecture of literature as well. Here are the guiding phases followed during the testing of the poem:

1. Read the poem aloud.

2. Students will be introduced to the genre of concrete poetry (definition)

3. You could ask them what kind of poetry is "Swan and Shadow" with some information about the poet John Hollander (1929).

4. You could ask if anyone has figured out how to read the poem so that it makes sense.

5. You could ask some students to read the poem aloud.

6. Explain how words change at the same time of the shape and the relationship.

7. Focus on the relationship between the poem ee form and the meaning.

8. You could ask students what they have noticed about the poem.

9. The way the poem was written (absence of punctuation, capital letters; all are the poet $\mathrm{s}$ choices to make the pattern or the visual image more concrete).

10. You could ask students about their first impression about the poem and particularly the image.

11. Study the metaphorical language of the poem.

12. You may propose to students to try to follow a particular pattern to write and get a concrete poem.

13. You could discuss the tone of the poem.

During the test procedure the researcher undertook a disguised observation in such a manner that his presence was unknown to the students. It is a controlled observation because it involves pre-arranged plans in other words, the researcher already knows in advance what to observe; it is a structured observation where the investigator has only to put a tick or to write the answers to the questions he planned before. Observation is an essential scientific tool in one ${ }^{\text {ee }}$ investigation because at the moment of the poem ${ }^{\text {es }} \mathrm{s}$ study students are incapable to give verbal reports of their feelings; therefore, a careful recording was necessary through noting.

The instrument used is considered as the second phase undertaken that began at the 
same time once the application of the test started. It is worth mentioning that observation though its limitedness of currently noting what is happening; it gives the researcher access to observe students ${ }^{\text {ee }}$ reactions while the teaching process and observing the teacher too can help the observer to clarify the success or failure of the test since the teacher is the performer of the test.

In a continuous dialogue with one ${ }^{\text {ee }}$ self; the researcher sees the reasonable use of a questionnaire which will help to best justify the test findings by collecting some quantitative information. The questionnaire encompasses two types of questions; namely open-ended questions and closed-ended questions. For the present study the former has been used to get variant responses and might be the logical way to give students the chance to report the difficulties they face anonymously as prescribed by Ellis (2004), that the questionnaire allows students to self-report their language learning aspects.

Therefore, the designed open-ended questions were administered to 46 students of the third year English L.M.D. students (groups C, D) during the break of literature session to ensure a high rate of students ${ }^{\text {ee }}$ feedback and the ability to provide them with the clarifications needed.

\section{FINDINGS, RESULTS AND ANALYSIS}

The researcher implicitly observed forty six students; the process lasted three hours which were separated by a ten minutes break. The task of observing was objective and structured guided by pre-planned questions. The first question which interested the observer is: What are studentse impressions when dealing with John Hollander"s "Swan and Shadow"? It is noticeable that some students were gazing at the picture of the poem trying to figure out what the shape is; the teacher asked about their impressions.

One also needed to know if students have been able to read the poem and this was the second question the researcher sought the answer. Hence, all students confirmed that they could be able to read the poem.

Then more specifically, the observer examined students ${ }^{\text {ee }}$ readings and wanted to discover studentse manner of performing poetry. Therefore, few read and the readings were not harmonious, it owes stops, and a lack of intonation too which make the poem like a piece of prose. As the primary concern of the research is to find out about the shape ${ }^{\text {ee }}$ effect; one was eager to know if students depicted the image of the poem as a swan or not. In that respect, some students reported that "Yes" they did instantly and others "No" they $\operatorname{didn}^{e e} t$ realize before this lecture. Our fifth concern was to answer the following questions: how does the picture influence on students ${ }^{\text {ee }}$ attitudes? How do they react in the classroom? It was a bit hard for the researcher to clarify this point yet the teachers ${ }^{\text {ee }}$ debatings pushed them to get involved and participate; some gave new ideas about the poem "s theme and particularly they were eager to know the objective of this shape as they asked "for what purpose was it written?" The above inquiries lead one to seek if the experience was interesting and whether or not they liked the poem; therefore, students responded all by yes and that it was clearly positive in the sense that they discovered a new genre or form of poetry.

Studying a concrete poem was an exploration and discovery for the 3rd Year English L.M.D. students seeing this genre of poetry for the first time and this was clearly obvious 


\section{Introducing the Visual Art through Concrete Poetry in the EFL Classroom: A Case Study}

observing students gazing at the image of the poem where some could not really know what it is; they did not identify the swan and its shadow shape before the lecture and others knew it immediately.

An important fact which was noticed is students ${ }^{\text {ee }}$ only focusing on words; fetching explanations in the dictionaries. It is true that is beneficial and helping to understand the poem "es theme yet it can be stressing too and more importantly as dealing with a concrete poem the shape loses its meaning and its visual role. Hence, by this way students may be unable to engage their thinking skill and imagination.

One ${ }^{e e}$ aim is to display the poem ${ }^{e e}$ s shape inside students ${ }^{\text {ee }}$ minds and the act of reading the poem would be the happening with the evolution of the process; the swan and its shadow moves, however, insisting of discussing only the objective of writing this literary piece and the analytical attitude can give a negative attitude toward poetry in general and in our case pushes some students to be only silent and afraid

The questionnaire is composed of six questions which were administered to the assisting students during our test who were only forty six. One e $^{\text {s }}$ aim is to obtain students ${ }^{\text {ee }}$ opinions about poetry in general and whether or not they are satisfied with their poetry learning, so that the researcher could probably suggest some ideas according adapted to their needs and interest.

\section{Question 01}

Do you believe that poetry is more difficult than prose?

The objective of this question is to know how students think about poetry as a literary genre; hence, out of forty-six respondents thirty two (32) (70\%) students answered that it is difficult than prose and only fourteen (14) (30\%) reported that it is not complex. So, by considering poetry difficult it might influence on students learning it being afraid to analyze or discuss a piece of poetry, in other words, the majority of students fear poetry and this can develop to a negative attitude towards it which can be an obstacle to participate or interact with the only thought that it is difficult.

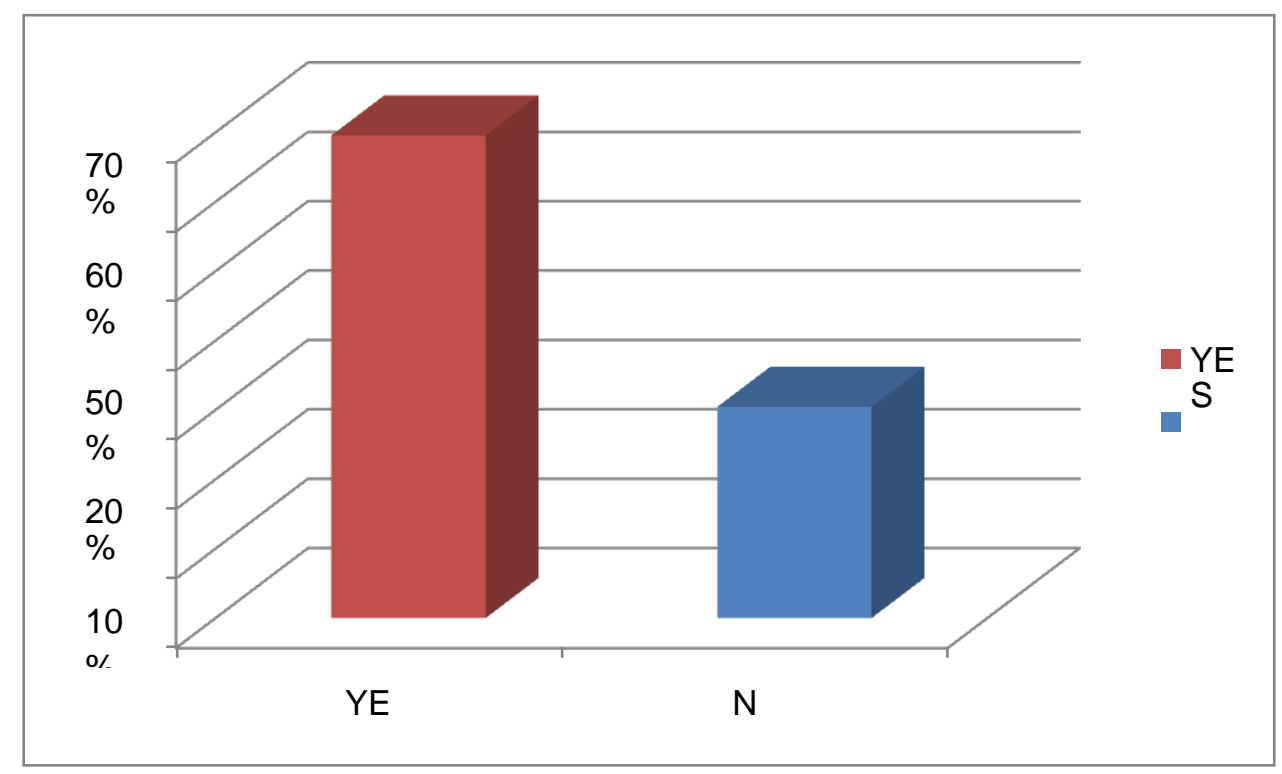




\section{Bar graph 01: Students' Attitudes towards Poetry}

The majority of students find poetry difficult than prose

Question 02

Does reading poetry develop your linguistic skills?

This question is giving students the chance to provide us with their opinions and basically with the effect of poetry on their language learning. As a result forty three (43) (93\%) students confessed that poetry does develop their linguistic skills, where only three (03) $(07 \%)$ claimed its non efficiency and this can be related to their absence of interest and motivation in studying poetry.

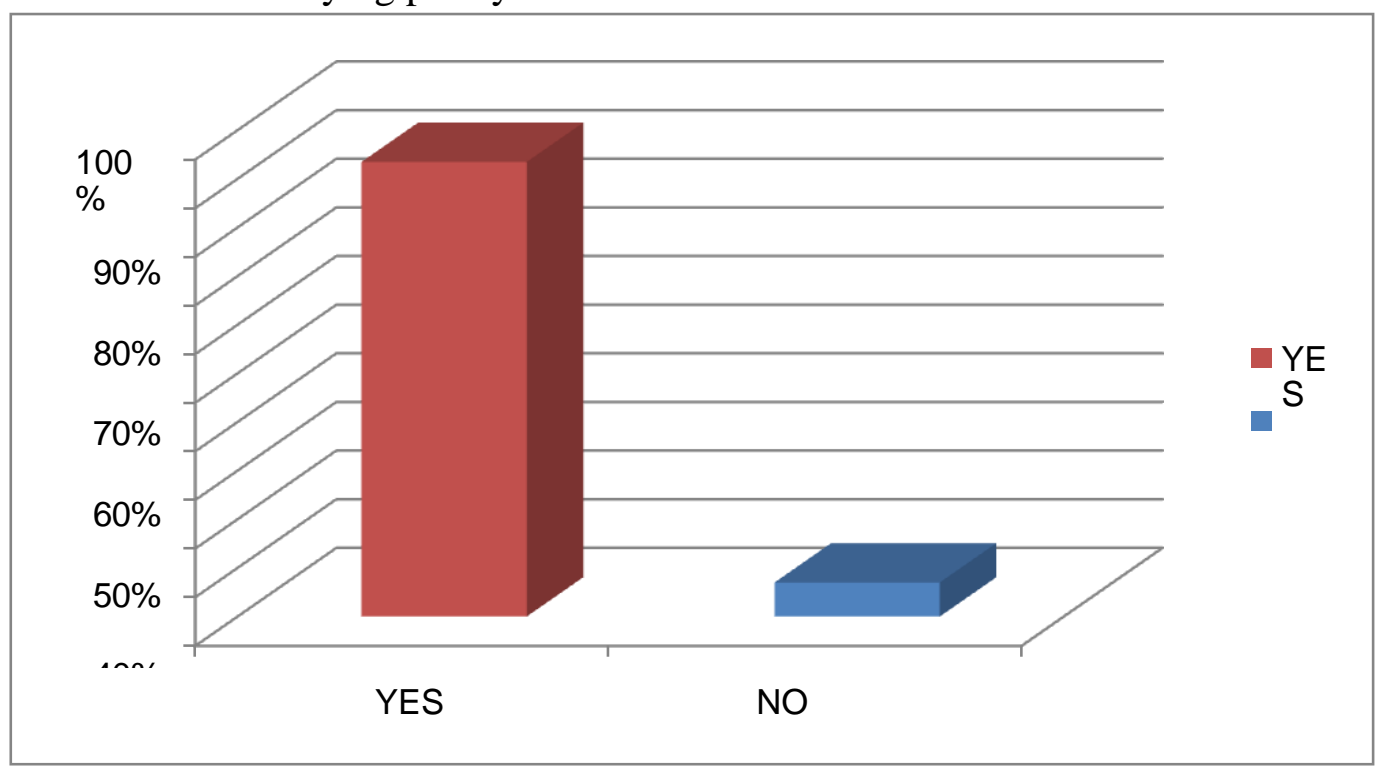

\section{Bar graph 02: The Potential of Poetry Enhancing Students' Abilities}

poetry develops the skills of the majority of students

Question 03

Have you studied different types of poetry? Explain

The aim of this question is to know if students have the knowledge of different types of poetry and which ones did they study and analyze practically.

The majority of students answered that they studied lyric poetry, epic, free verse, ballad and sonnet particularly a Shakespearean sonnet. Therefore, not all students are aware of the diverse forms of poetry and hence, their numerous roles towards the target language culture and their learning literature.

Question 04

Does your teacher of literature provide with some activities related to poetry or about the poem? Explain

Here students answered that their teacher gives them activities connected to the poem, they explained that they are asked to analyze it making extra researches as some stated. All the latter responses highlight an insisting task or a single task which students may refer to when dealing with poetry and which is"Analysis".

Asking this question may seem absurd or simple since it is logical for the 


\section{Introducing the Visual Art through Concrete Poetry in the EFL Classroom: A Case Study}

teacher to provide his students with activities especially when it is literature and poetry in particular. So, our aim was to discover what kind of activities whether they vary or not. Because having the same tasks repeated during the whole year may represent a kind of routine for students and probably lead them to dislike the lectures.

Question 05

When studying poetry what helps you to understand better the theme of the poem? Explain

The goal from asking the above question is to draw a distinction between the traditional form of poetry and the one of our actual research that is concrete poetry. It is implicitly targeted to discover studentse difficulties in studying poetry as well as to know if concrete poetry would be easier to study. As a result, the majority of students replied that the title of the poem plays a crucial role in guessing the poem "s theme; they explained how some words are essential to define as they called them "key words". So they emphasized that it is necessary to use the dictionary in order to be able to identify the poetes subject. Some others added that the biography of the poet is important too which would provide them with an insight about the poem or what they named "the context". Few noted that reading the poem many times in the classroom would allow them a better understanding of the theme.

Question 06

Does poetry as a literary piece of writing motivate you to write and participate in the classroom? Explain

This question proves the potential of poetry in the classroom in motivating students to be creative and provoking their thoughts to participate and share ideas in the classroom. So, the majority of students explained that poetry does truly motivate them whereas a few students relied that they are not motivated to study poetry and this is normal since they dislike it. Students reported that poetry helps them to express their ideas and most importantly to participate and exchange opinions with one another, so it gives them the chance to speak about the information they gathered about the poem or the poet. Others students specify poetry to an emotional experience to some extent, where they share feelings that provoke their imagination as one pointed out: "...living the author's moment..."

Others reported that poetry helps them in the writing skill where they learn different styles and expressions. One student claimed that it helps him producing his own poems. For those who answered "No" it is clear that they lack interest in poetry or simply they don ${ }^{e e} t$ like it or may be are not interested in participation.

One ${ }^{\text {ee }}$ testing to this particular genre of poetry is to acquaint it to both teacher and students and to discover whether it is worth exploring and studying or not. In fact, concrete poetry and particularly as a sample of it "Swan and Shadow" was a positive experience done with the forty six L.M.D. students.

At the beginning of the test, studentse silence showed their fear; may be asking how shall we deal with it or analyze it since this activity has a great influence or presence once mentioning poetry and even prose. Yet, the preplanned questions provided to the teacher stimulated them and thus started participating. 
After the first reading of the teacher students started participating by reading the poem without any difficulty and loudly. So, an active atmosphere took place and some students began to interact through reading.

The questionnaire which is considered as a pre-test helped one to localize poetry; and know how it is treated from a learning point that would help the researcher to suggest a probable of betterment after accomplishing our test and observation. The test was designed like a literature course to see whether concrete poetry is fruitful for the L.M.D. students or not. However, it has been argued that it is has been positive. Introducing this genre of poetry was motivating for students to participate and think what the shape is about. In fact, the triangulation provided the researcher with inter related data where some of studentse attitudes could be justified, the latter, did not only provide her with data yet she could observe new phenomena that need its own study and which is the reading of poetry.

From the following experience one deduces that the shape facilitates the learning of poetry where students enjoy the literature lecture stimulated by the visual shape of the poem. They can speak, interact and observe the beauty of this art. Therefore, the test positivity encourages one to try to suggest some activities and note some remarks to guarantee students ${ }^{\text {ee }}$ feedback.

\section{CONCLUSIONS}

The researcher tried to display how concrete poetry and the visual one can be useful in the literature class for its simplicity and beautiful variable shapes which may attract students ${ }^{\text {ee }}$ attention and interest in the literature classroom. The presence of poetry in the EFL classroom was debated for long because of its challenging language and difficult forms, yet it always enables the learner to experience multicultural thoughts and reveals also a certain fluidity of the human expressed emotions. The study of poetry is exciting; it allows students to develop their critical thinking by exchanging ideas and exposing their inquiries about the poem. Poetry can have diverse roles in the literature classroom and this depends on its form or rather its genre.

One cannot address the above mentioned benefits for all kinds of poetry; some are found with religious instructions, some are long poems which narrate a story or a heroic one and this can lead one to conclude that the choice of the lecture "s poem can have a role on influencing on the students ${ }^{\text {ee }}$ need and the course atmosphere.

Thus, teachers may have to be careful in picking up the right poem which will please students as readers and as learners. When students enjoy a poem they become consciously enthusiastic and involved to participate and share with their classmates and expose their deductions about its topic. However, by the frequent study of the traditional poems, poems which are presented in forms of stanzas, students may feel bored sometimes with their only preoccupation in finding out about the poem's theme. So, the researcher suggests introducing concrete poetry in the literature class, as a visual art which will try raising students ${ }^{\text {ee }}$ consciousness and observing skill. It could be too a way to have some genuinely shaped poems in one's classroom since the form of the latter poem may push students to be inventive and creative.

The work main findings exposed that concrete poetry really awakened students ${ }^{\text {ee }}$ thoughts to guess and deduce what is the purpose behind writing the shape of the poem. The experience allowed one to seek further about this genre of poetry connected to the technological advancements and ask whether it is possible to be used in an EFL classroom. That is why the researcher might need a further test or study about the use of concrete poetry with technology 


\section{Introducing the Visual Art through Concrete Poetry in the EFL Classroom: A Case Study}

tools. To conclude, EFL students need to be more aware of the art of expression and creativity via poetry as an important literary genre revealing some of its sound elements which attract students to perform it and to some extent make them curious readers who may explore human experiences.

\section{REFERENCES}

Arnold, Edward. (1973). Linguistics and Literature: An introduction to literary stylistics. UK: Raymond and Chapman.

Arnold, Matthew. (1880). Literary Theory: The basics. Netherlands: Routledge.

Carroll, Lewis. (2001). Jabberwocky and other poems. Canada: General Publishing.

Carty, Maria. (2005). Exploring Writing in the Content Areas: Teaching and Supporting Learners in any Subject. Canada: Pembroke Publishers

Collie Joanne, Slater Stephen. (1987). Literature in the Classroom: A Resource Book of Ideas and Activities. UK: Cambridge University Press.

Collie, J., and Slater, S. (1987). Literature in the Language Classroom. Cambridge: Cambridge University Press.

Dawes Roberts, P. (1986). How Poetry Works: The elements of English Poetry. England: Penguin Books.

Elliot, B.J. Marry M.D. (2002). Young Adult Literature in the Classroom: Reading it, teaching it, loving it. USA: International Reading Association.

Hedling, E, Britla Lagerroth, U. (2002). Cultural Functions of Intermedial Exploration. Netherlands: Rodopi Publications.

Hickman, Karrell . (2007). Literacy Projects for Student-Centered Classroom: Tips and lessons to engage students. USA: Corwin Press.

Higgins, Dick. (1984). Verbal, Visual Crossings, 1880-1980. Netherlands: Editions Rodopi.

Hirsch, Edward. (1999). How to Read a Poem and Fall in Love with Poetry. USA: Harvest book.

Holbrook, David. (1961). Teaching Literacy: A Creative Approach. UK: Continuum.

Hunley, Tom, C. (2007). Teaching Poetry Writing: A Five Canon Approach. UK: Multilingal Matters LTD.

Hunter, Paul, J. (1973). The Norton Introduction to Literature: Poetry. USA:

W.W. Norton and Company, INC.

Intrator, Sam, M. Scribner Megan. (2003).Teaching with Fire: Poetry that sustains the courage to teach. USA: Jossey Bass a Wiley Inprint.

Lown, Frederic, Wolinsky S.J. (1996). Reading and Writing Poetry with Teenagers. USA: Walch Publishing.

Maley, A. Moulding, S. (1985). Poem into Poem: Reading and Writing Poems with Students of English. Cambridge: Cambridge University Press.

Mikics, David. (2007). A New Handbook of Literary Terms. USA: Yale University Press.

Morison Jeff, Krobb Florian. (1997). Text into Image: Image into Text. Netherlands: Editions Rodopi.

Muller-Zettlemann, E. Rubik, M. (2005). Theory into Poetry New Approaches to the Lyric. Netherlands: Editions Rodopi.

Nayyer, Shamsi. (2004). Modern Teaching of English. India: Anmol Publications, PVT.LTD.

Perrine, Lawrence. (1973). Sound and Sense: An Introduction to Poetry. USA: Harcourt Brace 
Jovanovich, INC.

Robert, Edgar V. Jacobs Henry E. (2003). Literature: An introduction to Reading and Writing.USA: Pearson Prentice Hall.

Saper, J.C. (2001). Networked Art. USA: Regents of University of Minnesata. Sedgwick, Fred.

(2003). Teaching Poetry. London: Continuum

Solt, M.E. (1970). Experimental-Visual- Concrete: Avant- Garde Poetry

Comeaux, P. (1994). "Performing poetry: Centering the language arts programme". Contemporary Education, 65(2), 77-81.

Donen. (1974). "Poetry Ideas in Teaching Literature and Writing for Foreign Students". TESOL Quartly, Vol.16, No.4 pp. 489-502 from http://www.jstor.org/stable/3586467

Hadaway, L., Vardell, S., \& Young, T. (2001). "Scaffolding oral language Development through poetry for students learning language". The Reading Teacher, 54(8), 796-806.

Hanauer, D. (2003). "Multicultural moments in poetry: The importance of the unique". The Canadian Modern Language Review, 60, 69-87.

Hess, N. (2003). Real language through poetry: a formula for meaning making ELT Journal, 57 (1), 19-25.Journal of Language and Linguistic Studies, Vol.4, No.2, October 2008: "Using Poetry as a Model for Creating English Poems".

Lazar, G. (1996). "Exploring literary texts with the language learner". TESOL Quarterly, 30(4), 773-775.

Maher, J. (1986). (Ed.). "Poetry for instructional purposes: Authenticity and aspects of performance" In a Forum Anthology: 1979-83 Washington, D.C.: United States Information Agency: 327-333.

Margaret Church. (1946). "The First English Pattern Poems". PMLA, Vol. 61, No. 3 (Sep., 1946), pp. 636-650 from http://www.jstor.org/stable/459239

Mary Ellen Solt. (1970). “Concrete Poetry”. Books Abroad, Vol. 44, No. 3 pp. 421-425 from http://www.jstor.org/stable/40124559

SFU Educational Review "Pedagogical Approaches to Foreign Language Education: A discussion of poetic forms and culture" Volume 1 (2009), pp 49- 57

Thom Swiss. (1976). "Teaching Concrete Poetry: An Annotated Bibliography". College English, Vol. 38, No. 1 pp. 46-49 from http://www.jstor.org/stable/375987

\section{$\underline{A U T H O R ' S B I O}$}

Chahra BELOUFA is an assistant professor at the University of Djilali Liabes, Algeria and an autonomous researcher specialized in ELT, Shakespeare and Literature. She graduated from the University of Paul Valery, France in November 2017. Chahra has attended a lot of course studies in the Shakespeare Institute in Stratford-Upon-Avon. One in 2014; "Reviewing Shakespeare" and "The Living Shakespeare" in 26th May 2015. She has also been an active participant in the Shylock Project in Venice in June 2015, as well as presenting a paper in the 7th British graduate Shakespeare Conference, from the 4th to the 6th June 2015. Chahra BELOUFA is also a creative writer and a poetess; her published anthology of poems is entitled The Nightingale Whispers (2012). 